\title{
Irrigation and planting density affect river red gum growth
}

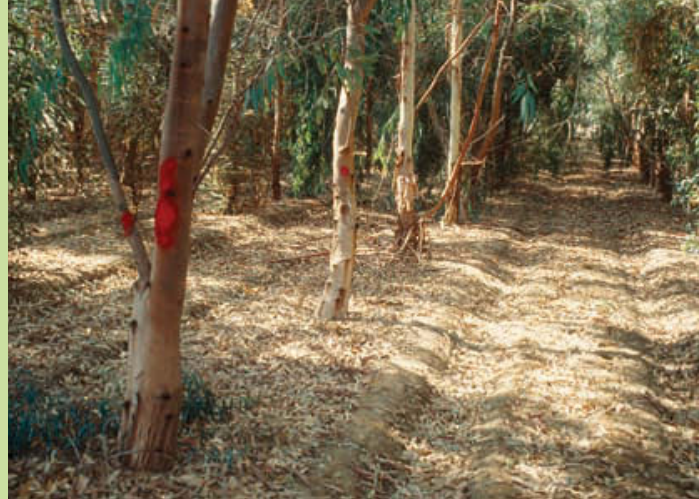

\author{
Stephen T. Cockerham \\ $\nabla$
}

In a 6-year study, production of river red gum, an excellent fuel-wood source, was evaluated for responses to three levels of irrigation, fertilization and planting density. Irrigation and planting density had the greatest influence on tree growth. Irrigation in the fifth and sixth years produced greater wood volume and weight per tree. Tree size was greatest in the wide spacing of the lower planting density. Fertilizer had no effect on any of the treatments. Per acre volume and weight yields were greater at the higher planting density, while individual tree height, diameter, volume and weight was greater at the low planting density. Growers seeking total wood volume per acre can increase yields with the higher density planting and irrigation.

$\mathrm{R}^{\mathrm{i}}$ iver red gum, Eucalyptus camaldulensis Dehnh., has the widest natural distribution in the world of any eucalypt and has few equals as a fuel-wood source (Chippendale and Wolf 1981). Because of its high heating value, it provides significant biomass use efficiency in cogeneration and small power systems (Jenkins and Ebeing 1985). One of the fastest-growing eucalyptus species in terms of height, diameter and tree volume (King and Krugman 1980), river red gum is well adapted to the inland valleys of Southern California (Standiford et al. 1982; Moore 1983b) and has potential for commercial fuel-wood production.

Eucalypt plantations have traditionally focused on the production of firewood, charcoal and pulpwood, but with genetic improvement are increasingly recognized as a resource for quality, higher value solid and reconstituted wood products. This is being driven by the sustainability of eucalyptus plantations (IUFRO 2000). Over the next 20 years, hardwood demand is expected to increase about $30 \%$ due to concerns over protection of the tropical rainforest and preference for wood products from certified sustainable forests. However, global oversupply of pulp and pulpwood in the 1990s kept eucalyptus prices low, limiting plantation establishment so that supply is not expected to keep up with the demand (Apsey and Reed 1996). Production and market opportunities for sustainable eucalyptus plantations will continue to grow for the next couple of decades.

Although the response of various eucalyptus species to nitrogen fertilizer varies (Turnbull and Pryor 1978), river red gum has been shown to respond to nitrogen fertilizer (Meskimen 1971; Crabb et al. 1983). However, because the yield response of river red gum is difficult to predict, commercial nitrogen-fertilization practices have been based on known responses of other tree crops (Moore 1983a). The management of nutrition and irrigation should improve commercial biomass yields for use of eucalyptus as an energy source (Standiford et al. 1982). Growing eucalyptus for fuel-wood could be commercially viable if intensive management to increase yield were both economical and practical.

Planting density can affect stand values because the high harvest cost of small trees produced at high densities may exceed the value of the fuel-wood produced (Hartsough and Nakamura 1990). At a density of about 650 trees per acre in a short-term harvest cycle, high yields may be possible without significantly reducing stem diameter (Moore 1983b).

\section{Southern California field trials}

In field trials with river red gum, the variables studied were irrigation, nitrogen fertilizer and planting density. The experimental site was in a Southern California inland valley at the UC Riverside Moreno Field Station. The soil was a Ramona fine sandy loam, with a soil moisture holding capacity of 0.11 inches water per inch at 1 to 23 inches soil depth; 0.18 to 0.20 inches water at the 23 to 68 inches depth; and 0.13 to 0.15 inches water at the 68 to 74 inches depth.

Irrigation water contained 550 parts per million (ppm) total dissolved solids, with $0.77 \mathrm{ppm}$ boron. (Boron is toxic to some crops at concentrations over 1.0 ppm.) Previous eucalyptus plantings at the site did not show sensitivity to boron (Moore 1983b). Annual rainfall was 24.3 inches in year 1 , 8.6 inches in year 2, 7.6 inches in year 3, 6.9 inches in year $4,10.0$ inches in year 5 and 6.3 inches in year 6 . The site's mean annual frost-free growing season is April 15 to Nov. 15, and it is located in Sunset western garden climate zone 19.

Irrigation was applied by furrow at 2.0 acre-feet per year (every 4 weeks), 4.0 acre-feet per year (every 2 weeks) and unirrigated control. Nitrogen fertilizer was applied annually as ammonium sulfate (21-0-0) shanked in 4 inches deep on one side of the tree row at 100 pounds per acre, 200 pounds per acre and unfertilized control. The plant density treatment was 302 trees per acre (spaced every 4 feet within row), 454 trees per acre (8 feet within row) and 907 trees per acre (12 feet within row), with 12 feet between all rows. The experimental design was a split plot in a split block, and the treatment design was a three factor-factorial. Irrigation 


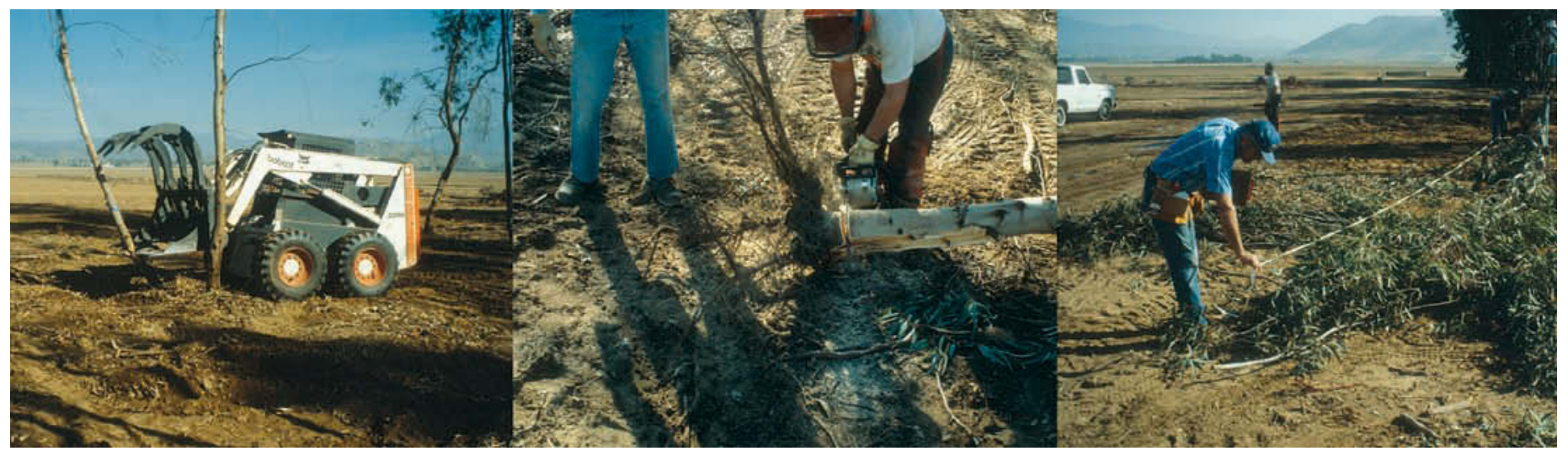

Left, record trees were pushed over and pulled up with a skid steer loader, then, center, the trunks were cut just above the root mass

for measuring. Right, final tree heights and diameters were measured with the tree lying on the ground.

nificantly greater in diameter than the unirrigated trees (table 2). Diameter was most affected by tree spacing with the greatest diameter at the lowest planting density (302 trees per acre), followed respectively by smaller trunks at the closer spacings and the smallest diameters at the greatest planting density (907 trees per acre).

Whole tree volume per tree. Whole tree volume on a per-tree basis was affected beginning in year 4 due to the affect of irrigation and plant density on tree diameter (table 3 ). In years 5 and 6 the volume per tree in the highest irrigation treatment was significantly greater than in the unirrigated treatment. The effect of tree planting density was significant, with volume per tree increasing with the wider-spaced, lower planting density of the trees.

Whole tree volume per acre. Irrigation increased the whole tree volume per acre (table 4). In years 5 and 6 the high irrigation rate produced more vol- ume per acre than the unirrigated trees. Volume production at the low irrigation rate was not different from either the high irrigation rate or no irrigation. Whole tree volume per acre was significantly higher with increasing plant density as more trees, even though smaller trees, produced greater total volume.

Weight. Total weight per tree increased with irrigation, while there was no benefit from the high irrigation rate (table 5). With branches smaller than 2 inches removed, the bole weights were not significantly different among the irrigation treatments. Planting density had the greatest effect on tree weight, with the heaviest trees, whole trees and boles produced in the lowest planting density.

\section{Density, irrigation affect growth}

Planting density and irrigation had the greatest influence on tree growth. Irrigation made a difference after the trees were well established and into the fifth and sixth years, producing larger trees, as shown by wood volume and weight per tree. Tree size was greatest in the open spacing of the lower planting density.

The planting density of 907 trees per acre yielded a mean tree size of 1.96 cubic feet and weighing 262.2 pounds green weight (139.0 pounds dry weight) per tree, while 302 trees per acre yielded a mean tree size of 4.36 cubic feet weighing 483.9 pounds green weight (256.5 pounds dry weight) per tree, an increase of $122 \%$ in size and $85 \%$ in weight.

For commercial production, the most wood was produced at the highest planting density per acre. Even though trees grown at the low planting density were bigger and heavier, they were not big enough or heavy enough to exceed the total wood volume produced per acre in the high tree population. Total per acre fuel-wood production was 1,310.5 cubic feet and 73 tons (38.7 tons
TABLE 2. Mean diameter breast height of river red gum $(n=16)$

\begin{tabular}{|c|c|c|c|c|c|}
\hline & Year 2 & Year 3 & Year 4 & Year 5 & Year 6 \\
\hline & & & inches. & & \\
\hline \multicolumn{6}{|l|}{ Irrigation } \\
\hline Unirrigated & $4.1 b$ & $3.7 b$ & $4.3 b$ & $5.1 \mathrm{~b}$ & $5.8 \mathrm{~b}$ \\
\hline $2.0 \mathrm{ac}-\mathrm{ft}$ & $4.4 a$ & $3.8 \mathrm{ab}$ & $4.4 a b$ & $5.3 a b$ & $6.1 \mathrm{ab}$ \\
\hline $4.0 \mathrm{ac}-\mathrm{ft}$ & $4.5 a$ & $4.0 \mathrm{a}$ & $4.6 a$ & $5.5 a$ & $6.4 a$ \\
\hline Significance* & ss & $s$ & s & $s$ & $s$ \\
\hline \multicolumn{6}{|l|}{ Fertilizer } \\
\hline Unfertilized & $4.3 a$ & $3.8 a$ & $4.4 a$ & $5.2 \mathrm{a}$ & $6.1 \mathrm{a}$ \\
\hline $100 \mathrm{lb} / \mathrm{ac}$ & $4.4 a$ & $3.8 a$ & $4.4 a$ & $5.3 a$ & $6.1 \mathrm{a}$ \\
\hline $200 \mathrm{lb} / \mathrm{ac}$ & $4.3 a$ & $4.0 a$ & $4.5 a$ & $5.4 a$ & $6.1 \mathrm{a}$ \\
\hline Significance & ns & ns & ns & ns & ns \\
\hline \multicolumn{6}{|l|}{ Plant density } \\
\hline 302 trees & $4.8 a$ & $4.3 a$ & $5.0 a$ & $6.0 a$ & $7.1 \mathrm{a}$ \\
\hline 454 trees & $4.6 b$ & $4.1 b$ & $4.6 b$ & $5.5 b$ & $6.3 b$ \\
\hline 907 trees & $3.6 c$ & $3.2 c$ & $3.8 c$ & $4.4 c$ & $4.9 c$ \\
\hline Significance & sss & sss & sss & sss & sss \\
\hline
\end{tabular}

* ns $=$ not significant; $s=$ significant at $P<0.05$; ss = highly significant at $P<0.01 ;$ sss = very highly significant.
TABLE 3. Mean whole tree volume* per tree of river red gum

\begin{tabular}{|c|c|c|c|c|c|}
\hline & Year 2 & Year 3 & Year 4 & Year 5 & Year 6 \\
\hline & & & cubic fe & & \\
\hline \multicolumn{6}{|l|}{ Irrigation } \\
\hline Unirrigated & $0.88 a$ & $0.83 a$ & $1.33 b$ & $2.08 \mathrm{~b}$ & $2.79 b$ \\
\hline $2.0 \mathrm{ac}-\mathrm{ft}$ & $0.95 a$ & $0.85 a$ & $1.36 \mathrm{~b}$ & $2.16 a b$ & $3.13 a b$ \\
\hline $4.0 \mathrm{ac}-\mathrm{ft}$ & $1.00 \mathrm{a}$ & $0.95 a$ & $1.60 a$ & $2.50 a$ & $3.50 a$ \\
\hline Significancet & ns & ns & $s$ & s & s \\
\hline \multicolumn{6}{|l|}{ Fertilizer } \\
\hline Unfertilized & $0.94 a$ & $0.87 a$ & $1.43 a$ & $2.22 a$ & $3.14 a$ \\
\hline $100 \mathrm{lb} / \mathrm{ac}$ & $0.96 a$ & $0.85 a$ & $1.39 a$ & $2.23 a$ & $3.05 a$ \\
\hline $200 \mathrm{lb} / \mathrm{ac}$ & $0.93 a$ & $0.91 a$ & $1.45 a$ & $2.27 a$ & $3.17 a$ \\
\hline Significance & ns & ns & ns & ns & ns \\
\hline \multicolumn{6}{|l|}{ Plant density } \\
\hline 302 trees & $1.19 a$ & $1.12 a$ & $1.86 a$ & $3.00 a$ & $4.50 a$ \\
\hline 454 trees & $1.08 a$ & $1.03 a$ & $1.57 \mathrm{~b}$ & $2.57 a$ & $3.33 b$ \\
\hline 907 trees & $0.65 b$ & $0.58 \mathrm{~b}$ & $0.99 c$ & $1.45 b$ & $2.03 c$ \\
\hline Significance & sss & sss & sss & sss & sss \\
\hline
\end{tabular}

* Volume $=d^{2}(0.001818 h+0.01636)($ Meskimen and Franklin 1978)

$\dagger \mathrm{ns}=$ not significant; $s=$ significant at $P<0.05$; ss = highly significant at $P<0.01$; sss $=$ very highly significant at $P<0.001$. 


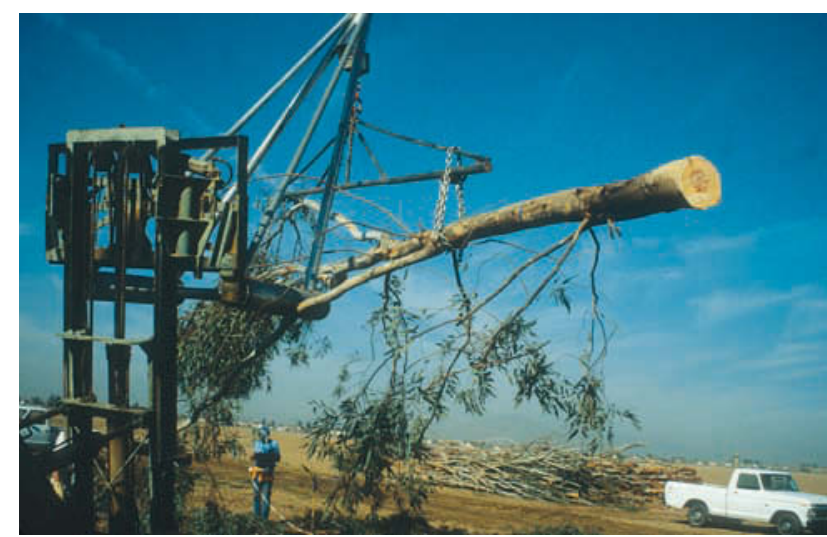

Finally, trees were weighed with a forklift and crane scale. The authors found that river red gum trees did best when irrigated with at least 4 acre-feet of water per year and at about 900 trees per acre; fertilizer did not have an effect.
TABLE 4. Mean whole tree volume* per acre of river red gum

\begin{tabular}{|c|c|c|c|c|c|}
\hline & Year 2 & Year 3 & Year 4 & Year 5 & Year 6 \\
\hline & & & ic feet/a & & \\
\hline \multicolumn{6}{|l|}{ Irrigation } \\
\hline Unirrigated & $441 a$ & $412 a$ & $664 b$ & $1,035 b$ & $1,388 b$ \\
\hline $2.0 \mathrm{ac}-\mathrm{ft}$ & $473 a$ & $422 a$ & $678 b$ & $1,077 a b$ & $1,559 a b$ \\
\hline $4.0 \mathrm{ac}-\mathrm{ft}$ & $497 a$ & $475 a$ & $796 a$ & $1,244 a$ & $1,739 a$ \\
\hline Significancet & ns & ns & $s$ & s & s \\
\hline \multicolumn{6}{|l|}{ Fertilizer } \\
\hline Unfertilized & $470 a$ & $434 a$ & $712 a$ & $1,106 a$ & $1,567 a$ \\
\hline $100 \mathrm{lb} / \mathrm{ac}$ & $479 a$ & $421 a$ & $694 a$ & $1,109 a$ & $1,519 a$ \\
\hline $200 \mathrm{lb} / \mathrm{ac}$ & $460 a$ & $452 a$ & $724 a$ & $1,130 \mathrm{a}$ & $1,582 a$ \\
\hline Significance & ns & ns & ns & ns & ns \\
\hline \multicolumn{6}{|l|}{ Plant density } \\
\hline 302 trees & $358 c$ & $339 c$ & $562 c$ & $904 b$ & $1,359 b$ \\
\hline 454 trees & $488 b$ & $463 b$ & $710 b$ & $1,163 a$ & $1,505 b$ \\
\hline 907 trees & $593 a$ & $527 a$ & $898 a$ & $1,317 a$ & $1,840 \mathrm{a}$ \\
\hline Significance & SSS & SSS & SSS & SSS & SSS \\
\hline
\end{tabular}

dry weight) with the widely spaced trees and up to 1,774.3 cubic feet and 118 tons ( 62.5 tons dry weight) in the closest spacing, an increase of $35 \%$ in volume and $63 \%$ in weight.

As potential for firewood, the smaller trees of the high-density planting retained $64 \%$ of the wood weight after removal of branches smaller than 2 inches, while the larger trees in the low-density planting retained $75 \%$. Still, the high plant population produced, per acre, 76 tons (40.3 tons dry weight) firewood compared with 55 tons (29.2 tons dry weight) in the low density. By year 6 , irrigation increased whole tree volume per tree by $25 \%$ and whole tree weight by $27 \%$. A similar irrigation effect of $27 \%$ increase in bole weight was not statistically significant, an indication of the large sapling variability among the record trees.

Based on our study, irrigation of at least 4.0 acre-feet per year would increase fuel-wood production in planting densities of at least 907 trees per acre in commercial production of river red gum. The cost of water may be a determining factor in the use of irrigation. Nitrogen fertilizer had no effect, and is uneconomical for river red gum production in a short rotation of 6 years.

\section{S.T. Cockerham is Superintendent of Ag-} ricultural Operations, UC Riverside. The California Department of Forestry provided partial funding for this project. The author acknowledges the contributions of Paul $W$. Moore, who was awarded the grant, designed the experiment and established the plots; and Gregory Stapleton and William Doughty, the technicians who kept the study going.

\section{References}

Apsey TM, Reed FLC. 1996. World timber resources outlook: Current perceptions with implications for policy and practice. Commonwealth Forestry Rev 75:155-60.

Chippendale GM, Wolf L. 1981. The natural distribution of Eucalyptus in Australia. Australian National Parks and Wildlife Service, Canberra. Special Pub No 6. 192 p.

Crabb TB, Melidosian MW, Whitesell CD, Schubert TH. 1983. Eucalyptus plantations for energy production in Hawaii: Progress report. Bioenergy Development Corp., US Forest Service and U Hawaii. Hilo, HI. 120 p.

Hartsough BR, Nakamura G. 1990. Harvesting eucalyptus for fuel chips. Cal Ag 44(1):7-8.

[IUFRO] International Union of Forestry Research Organizations. 2000. The future of eucalypts for wood production. Conference Communique. Launceston, Tasmania, Australia. $5 p$.

Jenkins BM, Ebeing JM. 1985. Thermochemical properties of biomass fuels. Cal $\mathrm{Ag}$ 39(3):14-6.

King JP, Krugman SL. 1980. Tests of 36 Eucalyptus species in northern California. Res Paper PSW-152. USDA Forest Service, Pacific Southwest Forest and Range Experiment Station, Berkeley, CA. 6 p.

Meskimen GF. 1971. Fertilizer tablets stimulate eucalyptus in Florida trial. USDA Forest Service Res Note SE-162. Southeastern Forest Experiment Station, Asheville, NC. $8 \mathrm{p}$.

Meskimen GF, Franklin EC. 1978. Spac-

ing Eucalyptus grandis in southern Florida. Southern J Applied Forestry 2(1):3-5.

Metcalf W. 1924. Growth of Eucalyptus in California plantations. UC Ag Exp Stn, Bull 380. Berkeley, CA. 61 p.

Moore PW. 1983a. Fertilization and irrigation of Eucalyptus in Southern California. In: Standiford RB, Ledig FT (eds.). Proc Workshop on Eucalyptus in California. Sacramento, CA. US Forest Service Gen Tech Rep PSW-69. p 90-2.
TABLE 5. Mean green weight (dry weight) per tree of river red gum after 6 years of irrigation, fertilizer and plant density treatments

\begin{tabular}{lcc}
\hline \hline & Total & Bole \\
\hline & $\ldots \ldots \ldots \ldots$ lb/tree $\ldots \ldots \ldots \ldots$ \\
Irrigation & & \\
Unirrigated & $326.5(173.0) \mathrm{b}$ & $238.2(126.2) \mathrm{a}$ \\
$2.0 \mathrm{ac}-\mathrm{ft}$ & $383.9(203.5) \mathrm{a}$ & $254.7(135.0) \mathrm{a}$ \\
$4.0 \mathrm{ac}-\mathrm{ft}$ & $413.1(218.9) \mathrm{a}$ & $302.3(160.2) \mathrm{a}$ \\
Significance * & sss & $\mathrm{ns}$ \\
Fertilizer & & \\
Unfertilized & $364.5(193.2) \mathrm{a}$ & $286.4(151.8) \mathrm{a}$ \\
100 Ib/ac & $371.2(196.7) \mathrm{a}$ & $249.5(132.2) \mathrm{a}$ \\
200 Ib/ac & $382.8(202.9) \mathrm{a}$ & $256.7(136.1) \mathrm{a}$ \\
Significance & $\mathrm{ns}$ & $\mathrm{ns}$ \\
Plant density & & \\
302 trees & $494.9(262.3) \mathrm{a}$ & $366.3(194.1) \mathrm{a}$ \\
454 trees & $398.3(211.1) \mathrm{b}$ & $298.8(158.4) \mathrm{a}$ \\
907 trees & $262.7(139.2) \mathrm{c}$ & $167.6(88.8) \mathrm{b}$ \\
Significance & sss & sss \\
\hline * ns = not significant; $\mathrm{s}=$ significant at $P<0.05 ;$ \\
ss = highly significant at $P<0.01 ;$ sss $=$ very highly \\
significant at $P<0.001$.
\end{tabular}

Moore PW. 1983b. Southern California trial plantings of Eucalyptus. In: Standiford RB, Ledig FT (eds.). Proc Workshop on Eucalyptus in California. Sacramento, CA. US Forest Service Gen Tech Rep PSW-69. p 14-7.

Pillsbury NH, Standiford RB, Costello LR, et al. 1989. Wood volume equations for central coast blue gum. Cal Ag 43(6):13-4.

Skolmen RG. 1983. Growth and yield of some Eucalypts of interest in California. In: Standiford RB, Ledig FT (eds.). Proc Workshop on Eucalyptus in California. Sacramento, CA. US Forest Service Gen Tech Rep PSW-69. p 49-57.

Standiford RB, Donaldson DR, Breece JR. 1982. Planting Eucalyptus for firewood. UC Division of Agricultural Sciences, Leaflet 21297. 4 p.

Turnbull JW, Pryor LD. 1978. Choice of species and seed sources. In: Hillis WE, Brown AG (eds.). Eucalypts for wood production. Division of Building Research, CSIRO. Melbourne, Australia. p 6-65. 